\title{
Antrenör Eğitim Sistemi Açısından 30978 Sayılı Antrenör Eğitimi Yönetmeliği’nin Değerlendirilmesi
}

\author{
Ömer ÖZBEY ${ }^{1}$, Halil Erdem AKOĞLU ${ }^{2 *}$, Bilge DONUK ${ }^{3}$ \\ ${ }^{1}$ Gençlik ve Spor Bakanlığı, Ankara. \\ ${ }^{2}$ Ankara Üniversitesi, Spor Bilimleri Fakütesi, Ankara. \\ ${ }^{3}$ İstanbul Üniversitesi-Cerrahpaşa, Spor Bilimleri Fakültesi, İstanbul.
}

Orijinal Makale

Gönderi Tarihi: 19.05.2020
Kabul Tarihi: 25.06.2020
DOI:10.25307/jssr.740064

Online Yayın Tarihi: 30.06 .2020

$\ddot{O} \mathbf{z}$

Bu araştırma, 6/8/2002 tarihli ve 24848 sayılı Antrenör Eğitim Yönetmeliği ile 14/12/2019 tarihli ve 30978 sayılı Antrenör Eğitimi Yönetmeliği'ni karşılaştırarak yönetmeliklerin farklı yönlerini ve bunların gerekçelerini ortaya koymak amacıyla yapılmıştır. Bu çalışmada kamu ya da özel sektör fark etmeksizin kurumsal imajı ve sürdürülebilir başarıyı sağlamak amacıyla önemli bir rol üstlenen antrenörlerin yetiştirilmesi için Gençlik ve Spor Bakanlığı tarafından yaklaşık 18 yıl arayla çıkarılan iki yönetmeliğin karşılaştırılması ve yeni çıkarılan Yönetmelik ile ortaya çıkan değişiklikler ortaya konulmaya çalışılmıştır. $\mathrm{Bu}$ araştırmada yatay yöntem yaklaşımı kullanılmıştır. Yatay yaklaşım tüm boyutları o döneme ait değişkenlerle yan yana getirerek farklılıkları saptamaya çalışan bir yöntemdir. Araştırmanın bulgularında her iki yönetmeliğin maddeleri karşılaştırılmalı olarak yatay tablolar şeklinde verilmiştir. Sonuç olarak mülga (eski, yürürlükten kaldırılan) Yönetmeliğe kıyasla yürürlükte olan (yeni çıkarılan, mevcutta olan) Yönetmeliğin birçok açıdan ülke sporunun ve halk sağlığının geliştirilmesinde en önemli unsur olan antrenörlerin eğitim süreçlerinde ve mesleki gelişimlerinde daha etkili olacağına ve geçmiş uygulamadaki birçok aksaklığın giderilmesine yardımcı olacağı sonucuna varılmıştır.

Anahtar kelimeler: Antrenör, Antrenör Eğitim Yönetmeliği, Spor Eğitimi.

\section{Evaluation of the Coach Training Regulation No. 30978 in terms of Coach Training System}

\begin{abstract}
This research was carried out in order to reveal different aspects of the regulations and justifications of these aspects, by comparing the Coach Training Regulation No. 24848 dated 6/8/2002 and the Coach Training Regulation No. 30978 dated $14 / 12 / 2019$. In this study, it has been tried to compare two regulations issued by the Ministry of Youth and Sports which have 18 years between them, and reveal amendments after the new Regulations, with the aim of raising the coaches, which play an important role in order to ensure their corporate image and sustainable success without making discrimination of public or private sector. Horizontal method approach was used in this research. Horizontal approach is a method that tries to detect differences by bringing all the dimensions side by side with the variables of that period. In the findings of the study, the articles of both regulations are comparatively presented in the form of horizontal tables. As a result, current Regulation, (which has been issued recently) in comparison with the abrogated (old, repealed) Regulation, will be more effective in the education processes and professional development of coaches, which is the most important factor in the development of the country's sports and public health, and current Regulation will help eliminate many problems in the past Regulation.
\end{abstract}

Keywords: Coach, Coach Education Regulation, Sport Education.

\footnotetext{
* Sorumlu yazar: Arş. Gör. Halil Erdem AKOĞLU, E-posta: heakoglu@ankara.edu.tr
} 


\section{GíRiş}

Günümüzde spor, kişisel ve toplumsal sağlı̆̆ı koruyucu ve geliştirici özellikleriyle önemli bir hizmet sektörü olarak kabul edilmektedir. Bu sektör küreselleşen dünyada teknolojinin gelişmesi ile kitlelere daha rahat ulaşabilmekte ve her geçen gün daha büyük bir endüstri haline gelmektedir. Aynı zamanda spor, ülke tanıtımı ve imajı açısından da büyük önem taşımaktadır. Uluslararası sportif başarılar bir ülkenin yabancı kamuoyunda tanıtılmasını sağlamaktadır. Bu nedenle bir ülkenin sportif açıdan gelişimi, toplumun spor yapmayı yaşam tarzı olarak benimsemesi, fiziksel okuryazlık kazanımlarını hayat boyu sürdürmesi ile uluslararası alanda üst düzey başarı sağlanmasının yanı sıra ülkenin tanıtımı ve bilinirliliği, imajı, kamu ve spor diplomasisi üzerinde de büyük önem taşımaktadır.

Literatür incelendiğinde, gençliğin gelişimi için sporun önemini vurgulayan birçok araştırmanın yer aldığı görülmektedir. Bireyler sportif faaliyetlerle, disiplin, özveri, azim, kimlik gelişimi, liderlik ve benzeri deneyimler edinmektedir (Conroy ve Coatsworth, 2006). Kişiler üzerindeki birçok faydasının yanında, sporun ayrıca ülke için politik, siyasal, iktisadi, sosyal ve kültürel açıdan da birçok faydası bulunmaktadır. Sporun doğrudan ve dolaylı etkileri düşünüldüğünde devlet yöneticileri, ülkedeki sporun gelişimini ve sürdürülebilir başarıyı sağlamak için politikalar üreterek uygulamaktadır (Özbey, Akoğlu ve Polat, 2019).

Sporcuların bilgi, beceri ve performanslarını arttırmada yardımcı olan ve sporda eğitim kavramı denilince ilk akla gelen kişiler antrenörlerdir (Johnson vd., 2011). Antrenör, sporcularının fiziksel ve psikolojik gelişimi üzerinde büyük etkiye sahip olan ve sporcular için rol model olarak görülen bir liderdir.

Sporcuların istenilen düzeye ulaşmasının temel şartı, farklı seviyelerde uygulama yaptırabilecek bilgili, becerikli, yetenekli ve iyi yetişmiş antrenörlere sahip olmaktır. Farklı spor dallarında yetişecek antrenörlerin ilgili spor dalının özelliği de dikkate alınarak bir model içerisinde eğitim alması ve mesleki olarak geliştirilmesi bir zorunluluktur. Bu nedenle temel ilkeleriyle bilimsel olanaklardan yararlanılarak yetişmiş bir antrenör, sporcularını da en iyi şekilde yetiştirmektedir (Sevim, Tuncel, Erol ve Sunay, 2001). Bu kapsamda sporcuların gelişiminde en büyük etki ve role sahip antrenörlerin eğitimi sporcu gelişimiyle paralellik göstermektedir.

Antrenörlerin eğitimsel gelişimi, kişisel ve özel bir amacı gerçekleştirmek için öğrenme yolları gerektiren karmaşık bir süreçtir (Knowles, Gilbourne, Borrie ve Nevill, 2001; Nelson ve Cushion, 2006). Bu süreci doğru bir şekilde uygulayan ülkeler sportif başarıyı yakalarken yanlış eğitim sistemi uygulayan ülkeler ise sportif başarı yakalamakta zorluk çekmektedir. Özellikle sporda gelişmiş ülkeler sporcuların yetişmesi ve başarısında büyük rolü olan antrenörleri yetiştiren eğitim programlarını bilimsel çalışmalara dayandırmışlardır (Sunay ve İmamoğlu, 1996).

Ülkemizde gençlik ve spor ile ilgili karar alan, uygulayan ve politikalar üreterek merkez ve taşra teşkilatlanması ile kurumun görev ve sorumluluklarını sevk ve idare eden kuruluş Gençlik ve Spor Bakanlığı'dır. Gençlik ve Spor Bakanlığı, antrenör eğitimi görev ve sorumluluğunu 21/5/1986 tarihli ve 3289 sayılı Gençlik ve Spor Hizmetleri Kanununun Ek 9 uncu maddesinin on yedinci fikrası ile 1 sayılı Cumhurbaşkanlığı Teşkilatı Hakkında 
Cumhurbaşkanlığı Kararnamesinin 189 uncu maddesinin birinci fikrasının (i) bendine dayanarak yürütmektedir.

$\mathrm{Bu}$ araştırmada 6/8/2002 tarihli ve 24848 sayılı Resmî Gazete'de yayımlanmış ve yaklaşık 18 yıl yürürlükte kalmış Yönetmelik ile 14/12/2019 tarihli ve 30978 sayılı Resmî Gazete'de yayımlanarak yürürlüğe giren Antrenör Eğitimi Yönetmeliği'nin karşılaştırılması ve revize edilen maddeler ile sistemsel olarak yeni eklenen maddeler ortaya konularak tartışılması amaçlanmıştır.

\section{METOT}

$\mathrm{Bu}$ araştırma, 6/8/2002 tarihli ve 24848 sayılı Antrenör Eğitim Yönetmeliği ile 14/12/2019 tarihli ve 30978 sayılı Antrenör Eğitimi Yönetmeliğinin karşılaştırarak farklı yönlerini ve bunların gerekçelerini ortaya koymak amacıyla yapılmış betimsel bir çalışmadır. Diğer bilimlerin aksine sosyal bilimlerde yapılan araştırmalarda doğrudan deney ya da ölçüm yapmak daha zordur. Sosyal bilimlerdeki bu eksikliğin giderilebilmesi için başvurulan yöntemlerden biri de karşılaştırmalı yöntemdir (Sunay, 2017). Alan yazın incelendiğinde karşılaştırmalı yöntemde benimsenen farklı yaklaşımlar bulunmaktadır. Bunlar; yatay, dikey, problem çözme, örnek olay, tanımlayıcı, açıklayıcı ve değerlendirici yaklaşımlardır. Bu araştırmada yatay yöntem yaklaşımı kullanılmıştır (Çubukçu, Yılmaz ve İnci, 2016). Yatay yaklaşım tüm boyutları o döneme ait değişkenlerle yan yana getirerek farklılıkları saptamaya çalışan bir yöntemdir (Ültanır, 2000).

\section{BULGULAR}

Araştırmada her iki yönetmelik tablolar halinde bölümlere ayrılarak karşılaştırılmıştır. Mülga Yönetmelikte bulunmayan ancak yürürlükte olan Yönetmeliğe eklenen kısımlar tabloda boş bırakılmıştır.

Tablo 1. Amaç, kapsam, dayanak ve tanımlar

\begin{tabular}{|c|c|c|}
\hline \multicolumn{3}{|c|}{$\begin{array}{c}\text { BİRİNCİ BÖLÜM } \\
\text { Amaç, Kapsam, Dayanak ve Tanımlar }\end{array}$} \\
\hline $\begin{array}{c}\text { 6/8/2002 tarihli ve } 24848 \text { sayılı Resmî } \\
\text { Gazete'de yayımlanan Antrenör Eğitim } \\
\text { Yönetmeliği }\end{array}$ & $\begin{array}{c}\text { 14/12/2019 tarihli ve } 30978 \text { sayılı } \\
\text { Resmî Gazete'de yayımlanan Antrenör } \\
\text { Eğitimi Yönetmeliği }\end{array}$ & Değişikliklerin Gerekçesi \\
\hline $\begin{array}{l}\text { Madde } \mathbf{1}-\mathrm{Bu} \text { Yönetmeliğin amacı; } \\
\text { sporcuların yetiştirilmelerinde spor dalları } \\
\text { itibariyle görev alacak antrenörlerin eğitimleri } \\
\text { ve sınıflandırılmaları ile ilgili esas ve usulleri } \\
\text { belirlemektir. }\end{array}$ & $\begin{array}{l}\text { Madde } 1-(1) \mathrm{Bu} \text { Yönetmeliğin amacı, } \\
\text { ilgili spor dalına performans } \\
\text { ve/veya rekreatif amaçlı katılan her } \\
\text { yaştaki bireylerin eğitiminde görev } \\
\text { alacak antrenörlerin eğitimi ve görev } \\
\text { alanları ile ilgili usul ve esasları } \\
\text { belirlemektir. }\end{array}$ & $\begin{array}{l}\text { Mülga (eski, yürürlükten kaldırılan) } \\
\text { Yönetmelikten farklı olarak yürürlükte } \\
\text { olan (yeni çkarılan, mevcutta olan) } \\
\text { Yönetmeliğe performans ve rekreatif } \\
\text { katılım eklenmiş ve yalnızca sporcular } \\
\text { değil her yaştaki bireylerin eğitimine de } \\
\text { atıfta bulunulmuştur. }\end{array}$ \\
\hline $\begin{array}{l}\text { Madde } 2-\text { Bu Yönetmelik; sualtı sporları, } \\
\text { dağcılık, otomobil sporları ve izcilik dışındaki } \\
\text { spor dallarında; Gençlik ve Spor Genel } \\
\text { Müdürlüğü antrenör eğitimi programları ile bu } \\
\text { programların uygulama, esas ve usullerini } \\
\text { kapsar. }\end{array}$ & $\begin{array}{l}\text { Madde } 2-(1) \text { Bu Yönetmelik, spor } \\
\text { federasyonlarının antrenör eğitim } \\
\text { programları ile bu programların } \\
\text { uygulanmasına ilişkin usul ve esasları } \\
\text { kapsar. }\end{array}$ & $\begin{array}{l}\text { Usulde ve uygulamada birliğin } \\
\text { sağlanması amaciyla tüm federasyonlar } \\
\text { tek çatı altına alınmış ve kapsam dışı olan } \\
\text { Türkiye Sualtı Sporları, Dağcılık, } \\
\text { Otomobil Sporları ve İzcilik } \\
\text { Federasyonları da Yönetmelik kapsamına } \\
\text { dahil edilmiștir. }\end{array}$ \\
\hline $\begin{array}{l}\text { Madde } 3 \text { - Bu Yönetmelik, } 3289 \text { sayılı } \\
\text { Gençlik ve Spor Genel Müdürlüğünün Teşkilat } \\
\text { ve Görevleri Hakkında Kanunun } 2 \text { ve } 10 \text { uncu } \\
\text { maddesine dayanılarak hazırlanmıştır. }\end{array}$ & 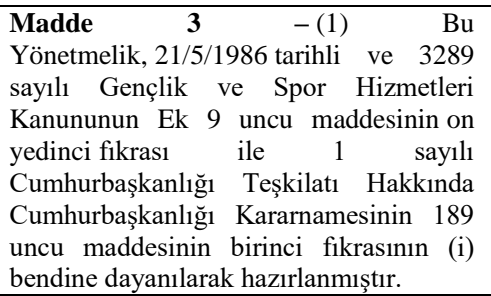 & $\begin{array}{l}3289 \text { sayılı Gençlik ve Spor Hizmetleri } \\
\text { Kanunu'nun dayanak olan mülga } \\
\text { maddeleri çıkartılmış ve } 1 \text { sayılı } \\
\text { Cumhurbaşkanlığı Teşkilatı Hakkında } \\
\text { Cumhurbaşkanlığı Kararnamesi'nin ilgili } \\
\text { maddeleri dayanak olarak eklenmiştir. }\end{array}$ \\
\hline
\end{tabular}


Özbey, Ö., Akoğlu, H.E. ve Donuk, B. (2020). Antrenör eğitim sistemi açısından 30978 sayılı Antrenör Eğitimi Yönetmeliği’nin değerlendirilmesi. Spor Bilimleri Araştırmaları Dergisi, 5(1), 95-110.

Tablo 1'de 6/8/2002 tarihli ve 24848 sayılı Resmî Gazete'de yayımlanan mülga Antrenör Eğitim Yönetmeliği ile 14/12/2019 tarihli ve 30978 sayılı Resmî Gazete'de yayımlanan Antrenör Eğitimi Yönetmeliğinin Birinci bölümü olan “Amaç, Kapsam, Dayanak ve Tanımlar” bölümünün karşılaştırılması yapılmış ve yapılan değişikliklerin gerekçeleri gösterilmiştir.

Tablo 2. Antrenör eğitim programı ve sınava ilişkin esaslar

\section{İKINCİ BÖLÜM}

Antrenör Eğitim Programı ve Sınava Ilişkin Esaslar

6/8/2002 tarihli ve 24848 sayılı Resm

Gazete'de yayımlanan Antrenör Eğitim Yönetmeliği
14/12/2019 tarihli ve 30978 sayıl

Resmî Gazete'de yayımlanan Antrenör Eğitimi Yönetmeliği
Madde 5 - Antrenör eğitim kurslar1, federasyonların, gençlik ve spor il müdürlükleri ile sporla ilgili kurum ve kuruluşların ihtiyaçları esas alınarak ilgili spor dalı federasyonunun iş birliği ve teknik desteği ile Daire Başkanlığınca düzenlenir.
Madde 5 -(1) Antrenör eğitim programina katılacak aday sayıs1, adayların talepleri de dikkate alınarak ilgili federasyonun görüşü doğrultusunda Bakanlık tarafindan belirlenir.

(2) Antrenör eğitim programına katılacak aday sayısı ile şartları, başvuru yeri, süresi ve diğer hususlar, Bakanlık ve ilgili federasyonun internet sitesinde duyurulur.

MADDE 7 - (1) Antrenör eğitim programına katılacak adaylarda aşağıdaki şartlar aranır:

a) Türkiye Cumhuriyeti vatandașı olmak.

b) En az lise veya dengi okul mezunu olmak.

$\begin{array}{lrr}\text { Madde } & \text { 6--Kademeler } & \text { itibariyle } \\ \text { Antrenör eğitim } & \text { kurslarına } & \text { katılacaklarda }\end{array}$ aşağıdaki şartlar aranır:

a) En az lise veya dengi okul mezunu olmak, (Bütün kademeler için geçerli olup, Milli sporcularda tahsil şartı aranmaz.)

c) Taksirli suçlar hariç olmak üzere ağır hapis veya 6 aydan fazla hapis veyahut affa uğramış olsalar bile devletin şahsiyetine karșı ișlenen suçlarla; zimmet, ihtilas, irtikap, rüşvet, hırsızlık, dolandırıcılık, sahtecilik, inancı kötüye kullanma, hileli iflas gibi yüz kızartıcı veya şeref ve haysiyeti kırıcı suçtan veya istimal ve istihlak kaçakçılığı hariç kaçakçılık, resmi ihale ve alım satımlara fesat karıştırmak, devlet sırlarını açığa vurmak suçlarından dolayı tecil edilmiş olsa dahi ceza almamış olmak, Ancak, başvurunun fazla olması halinde yukarıdaki șartların yanında sırasıyla; ilgili branşta milli sporcu olmak, üniversitelerin beden eğitimi ve spor eğitimi veren yüksek öğrenim kurumları ile diğer üniversite ve yüksekokullardan mezun olmak, yabancı dil bildiğini belgelemek ve en az 5 yıl lisanslı sporcu olmak tercih sebebidir. c) Spor dallarının özelliğine göre ilgili federasyon tarafindan hazırlanan antrenör eğitim talimatında belirlenen sağlık şartlarını taşımak

ç) Taksirli suçlar ile kısa süreli hapis cezasına seçenek yaptırımlara çevrilmiş veya aşağıda sayılan suçlar dışında tecil edilmiş hükümler hariç olmak üzere, kasten işlenen bir suçtan dolayı bir yıl veya daha fazla süreyle hapis cezasına ya da affa uğramış olsa bile Devletin güvenliğine karşı suçlar, anayasal düzene ve bu düzenin ișleyișine karșı suçlar, zimmet, irtikâp, rüşvet, hırsızlık, dolandırıcılık, sahtecilik, güveni kötüye kullanma, hileli iflas, ihaleye fesat karıştırma, edimin ifasına fesat karıştırma, suçtan kaynaklanan malvarlığı değerlerini aklama, kaçakçılık veya cinsel dokunulmazlığa karşı suçlar, fuhuş, uyuşturucu ve uyarıcı madde imal ve ticareti, kullanımı, kullanımını kolaylaştırma, kullanmak için satın alma, kabul etme veya bulundurma, haksız mal edinme, şike ve teşvik primi suçlarından mahkûm olmamak.

(3) Başvurunun ilan edilen kontenjandan fazla olması halinde, antrenör eğitim programı uygulama eğitimine katılacak olanlar, ilgili federasyonun antrenör eğitim talimatında belirleyeceği şartlar doğrultusunda sıralanır.

MADDE 8 -(1) Antrenör eğitim programı, federasyonların, gençlik ve spor il müdürlükleri ile sporla ilgili diğer kurum ve kuruluşların ihtiyaçları esas alınarak temel eğitim ve uygulama eğitimi olarak düzenlenir.
Değişikliklerin Gerekçesi

Mülga Yönetmelikte, Federasyonların kurs ilanları için herhangi bir ilan edilme süresi yer almamaktadır. Yürürlükte olan Yönetmelik ile açılacak eğitim programları hakkında tüm detayların ilgili federasyonun Antrenör Eğitimi Talimatlarında, başvuru ve ilan gibi hususların ise hem Bakanlığın hem de ilgili federasyonun internet sitesinde ilan edilmesi hükmü getirilmiştir. Bu madde ile var olan müphemlik ortadan kaldırılmış, adayların yaşadığı mağduriyet engellenmiş ve yapı kurumsal hale getirilmiştir.

- 7 nci maddenin birinci fikrasının (b) bendi ile mülga Yönetmelikte milli sporculardan tahsil şartı aranmaz ibaresi kaldırılmış ve adayların belli bir eğitim seviyesinde olma şartı getirilmiştir.

- (c) bendinde ise her federasyon için farklı sağlık koşulları gerekmesi sebebiyle spor dallarının özelliğine göre federasyonların Antrenör Eğitim Talimatlarında sağlık şartlarını belirlemesine imkan sağlamıştır.

- Mülga Yönetmelikte belirtilen suçlara ek olarak (ç) bendinde, değişen ceza kanunları ve süreleri ile diğer değişen mevzuat hükümleri yürürlükte olan Yönetmeliğe teselsül ettirildiği görülmektedir.

- Üçüncü fikra kapsamında ise kontenjan ile ilgili şartlar Yönetmelik hükmüne bağlanmayarak ilgili federasyon tarafından istenilen şartların kendilerince belirlemeleri hükmü getirilmiştir.

$\mathrm{Bu}$ madde ile antrenör eŏitim sisteminde köklü değişiklik yapılarak, eğitim programı ikiye ayrılıp temel ve uygulama eğitimi olarak düzenlenmiştir.

Teorik derslerin yer aldığı temel eğitim bölümü Gençlik ve Spor Bakanlığı tarafından ya da Bakanlıkça yetkilendirilecek eğitim kurumu tarafından uzaktan eğitim yöntemiyle düzenlenecektir. 
Özbey, Ö., Akoğlu, H.E. ve Donuk, B. (2020). Antrenör eğitim sistemi açısından 30978 sayılı Antrenör Eğitimi Yönetmeliği’nin değerlendirilmesi. Spor Bilimleri Araştırmaları Dergisi, 5(1), 95-110.

Tablo 2 (Devamı). Antrenör eğitim programı ve sınava ilişkin esaslar 6/8/2002 tarihli ve 24848 sayılı Resmî 14/12/2019 tarihli ve 30978 sayılı Resmî Gazete'de yayımlanan Antrenör Eğitim Gazete'de yayımlanan Antrenör Değişikliklerin Gerekçesi Yönetmeliği Ĕ̆itimi Yönetmeliği

Uygulama eğitimi

MADDE $\quad 10 \quad-(1) \quad$ Uygulama eğitimi, antrenörlük kademeleri arasındaki geçiş süreleri ve başvurular da dikkate alınarak her kademe için yılda en az bir kez resen veya Bakanlık talimatı üzerine ilgili federasyon, gerekli hallerde ise Bakanlık tarafindan düzenlenir.

\begin{abstract}
Öğretim Elemanlarının Görevlendirilmeleri Madde 11 - Antrenör eğitim programında yer alan derslerde öğretim elemanlarının görevlendirilmeleri aşağıdaki şekilde olur; b) Özel eğitim programına ait derslerin öğreticileri ilgili spor dalında; ihtisas sahibi ögretim elemanı unvanına sahip olanlar ile IV. Kademe (Başantrenör) veya V. Kademe (Teknik Direktör) antrenör belgesine sahip olan kişiler arasından ilgili federasyonca seçilir. Ancak, ilgili spor dalında IV. Kademe (Başantrenör) ve V. Kademe (Teknik Direktör) antrenör belgesine sahip ve ihtisas sahibi öğretim elemanı bulunmaması halinde, konusunda federasyonca bilgisi ve tecrübesi onaylanan eğiticilere eğitim programında görev
\end{abstract} verilebilir.

\section{Devam Zorunluluğu}

Madde 19 - Kursa en fazla bir tam gün veya 2 yarım gün mazeretsiz katılmayan kursiyerlerin kursla ilișkileri kesilir.

Kurs süresince 3 günü geçen raporlar devamsızlıktan sayılır ve kursiyerlerin kursla ilişkileri kesilir.

\begin{abstract}
Uygulama eğitimi eğiticilerinin niteliği MADDE 11 -(1) İlgili spor dalı uygulama eğitiminde görev alan eğiticilerin aynı spor dalında en az bir üst kademe antrenörlük belgesine sahip olması gerekir. Üst kademe antrenörlük belgesine sahip eğitici bulunmaması halinde aynı kademe belgeye sahip eğitici görevlendirilebilir.

(2) Bakanlık tarafindan uygun görülmesi halinde antrenör uygulama eğitiminde spor uzmanı, yabancı spor uzmanı veya yabancı antrenör görevlendirilebilir.
\end{abstract}

\section{Devam zorunluluğu}

MADDE 12 - (1) Uygulama eğitiminde devamsızlık süresi, her ne sebeple olursa olsun toplam ders saatinin yüzde onunu geçemez.

(2) Birinci fikrada belirlenen sürenin üzerinde devamsizlık yapan antrenör adaylarının uygulama eğitimiyle ilişikleri kesilir.

Uygulama eğitimi sınav kurulu ve
komisyonları

MADDE 13 -(1) Sinav Kurulu; Bakan tarafindan, Bakanlık personeli arasından görevlendirilecek bir başkan, dört asıl ve aynı sayıda yedek üyeden oluşur. Sınav Kurulu, başkan ve üyelerinin tamamının katılımı ile toplanır ve kararlar oy çokluğu ile alınır. Ası üyelerin herhangi bir nedenle katılamamalar halinde yedek üyeler tespit sırasına göre Sinav Kuruluna katılır. Sinav Kurulunun sekretarya hizmetleri Bakanlık tarafindan yürütülür

(2) Kurul, sınavlara ilisskin hususların tespit edilmesi, sınavların yapılması, yaptırılması, sonuçlarının değerlendirilmesi, ilan edilmesi, itirazların sonuçlandırılması ve sınavla ilgili diğer işlemlerin komisyon/komisyonlar marifetiyle yürütülmesinden sorumludur.

(3) Sinav komisyonu/komisyonları; Sinav Kurulu tarafindan federasyonun teklifi üzerine görevlendirilecek bir başkan, en az iki asıl ve aynı sayıda yedek üyeden olușur. Sınav Kurulu tarafindan gerek görülmesi halinde ayrıca Bakanlık personeli arasından bir veya birden fazla üye görevlendirilebilir.

(4) Sınav komisyonu/komisyonları başkan ve üyeleri; boşanmış olsalar dahi eşlerinin,

üçüncü dereceye kadar (bu derece dâhil) kan ve kayın hısımlarının ve evlatlık ilişkisi içinde bulunanların katıldıkları sınavlarda görev alamazlar. Bu durumda olanların yerlerine sırasıyla yedek üyeler katılır.

(5) Sinav komisyonunun sekretarya hizmetleri, ilgili federasyon tarafindan yürütülür.
Uygulama eğitimine ilişkin düzenlemeler ise 3289 sayılı Kanun kapsamında kurulan spor federasyonları ile Bakanlığın iş birliği içerinde hazırlayacakları ilgili spor dalı federasyonlarının Antrenör Eğitim Talimatlarında belirtilecektir. Birinci fikra ile federasyonlarca eğitimin açılması için aranan belirli sayı sağlanmasa dahi adayların sistem üzerinden başvurmaları halinde uygulama eğitimlerinin mecburi açılması hükmü getirilmiştir. Bu sayede 1. ve 2 . kademedeki yığılma önlenerek üst kademe antrenör olabilme imkanı getirilmiştir. $\mathrm{Bu}$ sayede birçok federasyonda olan üst kademedeki antrenör sayısındaki eksiklik sona erdirilmeye çalışılmıştır.

Özellikle yeni kurulan federasyonlar tarafindan uygulanması mümkün olmayan mülga Yönetmelikteki bu madde, işlevsel hale getirilerek 4 . ve 5 . kademe şartı kaldırılmış, kademe belirtilmeden açılacak uygulama eğitimi kademesine göre üst ya da denk kademe antrenörlerin uygulama eğitimlerini vermeleri hükmü getirilmiştir. Yine işlevsellik açısından ilgili spor dalında antrenör bulunmaması halinde; spor uzmanı, yabanc1 spor uzmanı veya yabancı antrenör görevlendirilebileceği hükmü eklenerek oluşabilecek yönetimsel tıkanıklık çözüme kavuşturulmuştur.

Düzenlenecek eğitimlerin süresi
değişkenlik göstereceği için devamsızlık süresinin yüzde olarak oranlanmasının hem eğiticiler hem de eğitime katılan adaylar için daha faydalı olacağ 1 düşünülmüşsür.

Bu madde ile uygulama eğitim ve
sinavları federasyonlar tarafindan
oluşturulacak komisyon tarafindan
yürütülecektir. Bu şekilde eğitim ve
sinavda belirli bir kalite yakalanacak ve
olası itirazlar sinav komisyonu ve kurul
tarafindan değerlendirilecektir.
tarafindan değerlendirilecektir. 
Özbey, Ö., Akoğlu, H.E. ve Donuk, B. (2020). Antrenör eğitim sistemi açısından 30978 sayılı Antrenör Eğitimi Yönetmeliği’nin değerlendirilmesi. Spor Bilimleri Araştırmaları Dergisi, 5(1), 95-110.

Tablo 2 (Devamı). Antrenör eğitim programı ve sınava ilişkin esaslar 6/8/2002 tarihli ve 24848 sayıl Resmî 14/12/2019 tarihli ve 30978 sayıl Resm Gazete'de yayımlanan Antrenör Eğitim Gazete'de yayımlanan Antrenör Yönetmeliği

\section{Sınav Sonuçlarına İtiraz Hakkı}

Madde 18 - Antrenör eğitim kurslarının yazılı ve sözlü sınavlarının değerlendirme sonuçlarına kursiyerler kurs bitim tarihinden itibaren 30 gün içinde itiraz edebilir. Puan toplama hatalarına yapılacak itirazlar 7 gün içerisinde (postada geçen süre hariç) Daire Başkanlığına yapılır. İtirazlar 30 gün içerisinde Daire Başkanlığınca sonuçlandirılır.

\section{Gazete'de yayımlanan Antrenör Değişikliklerin Gerekçesi} Ĕgitimi Yönetmeliği

Sınav sonuçlarına itiraz

MADDE 15 - (1) Adaylar, sinav sonuçlarının ilan edilmesinden itibaren beş iş günü içerisinde, duyuruda belirtilen usulde itiraz edebilir. İtirazlar, on beş iş günü içerisinde incelenerek karara bağlanır.

Müsabakası yapılmayan spor dalları
MADDE $17 \quad-(1)$ Müsabakası
yapılmayan ve antrenörlük kapsamı
dışında kalan her türlü rekreatif amaçlı
fiziksel ve zihinsel egzersizleri içeren
eğitim programlarının uygulanmasında
görev alan kişilerin eğitimleri ve görev
alanları ile ilgili usul ve esaslar, ilgili
federasyonun teklifi ve Bakanlığın uygun
görüşü doğrultusunda eğitim talimatı ile
düzenlenir.

İtirazlara ilişkin bu madde ile komisyon marifetiyle gerçekleştirilerek iş ve işlemler kurumsallık kazanmıştır. Bu sayede itirazları, sadece adaylara eğitim veren ve sınavı yapan kişiler değil o kişiler ile birlikte komisyon ve kurulda inceleyerek hakkaniyetli neticeye ulaşılmasının hedeflendiği görülmektedir.

Mülga Yönetmelikteki kavram karmaşalarından bir diğeri de hangi spor dalları için antrenör ya da eğitmen ifadelerinin kullanılmasıydı. Bu madde ile antrenör ve eğitmenin görev alanları ayrılmış ve kişilerin hangi hallerde eğitmen olabileceği netleştirilmiştir. Ayrıca Yönetmelikte belirlenen şartların sağlanması halinde kişilere hem antrenör hem de eğitmen olabilme imkanı getirilmiştir.

Tablo 2'de 6/8/2002 tarihli ve 24848 sayılı Resmî Gazete'de yayımlanan mülga Antrenör Eğitim Yönetmeliği ile 14/12/2019 tarihli ve 30978 sayılı Resmî Gazete'de yayımlanan Antrenör Eğitimi Yönetmeliğinin ikinci bölümü olan "Antrenör Eğitim Programı ve Sınava Ilişkin Esaslar" bölümünün karşılaştırılması yapılmış ve yapılan değişikliklerin gerekçeleri gösterilmiştir.

Tablo 3. Antrenörlük kademeleri, kademelerin görev tanımları, geçiş işlemleri, hak ve muafiyetler, belge verilmesi ve iptali

\begin{tabular}{|c|c|c|}
\hline \multicolumn{3}{|c|}{$\begin{array}{l}\quad \text { ÜÇÜNCÜ BÖLÜM } \\
\text { leri, Kademelerin Görev Tanımları, Geçiş İşlemleri, } \\
\text { Muafiyetler, Belge Verilmesi ve İptali }\end{array}$} \\
\hline $\begin{array}{l}\text { 6/8/2002 tarihli ve } 24848 \text { sayılı Resmî } \\
\text { Gazete'de yayımlanan Antrenör Eğitim } \\
\text { Yönetmeliği } \\
\text { Antrenör Sınıflandırılması } \\
\text { Madde } 7 \text { - Antrenörler her spor dalında } \\
\text { (V) kademe olmak üzere aşağıdaki şekilde } \\
\text { sinıflandırılır; } \\
\text { a) I. Kademe, (Yardımcı Antrenör) } \\
\text { b) II. Kademe, (Antrenör) } \\
\text { c) III. Kademe, (Kıdemli Antrenör) } \\
\text { d) IV. Kademe, (Başantrenör) } \\
\quad \text { e) V. Kademe. (Teknik Direktör) } \\
\text { Görev Alanları } \\
\text { Madde 8 - Her kademedeki antrenör } \\
\text { lisansına sahip olanlar aşağıdaki alanlarda } \\
\text { görev yaparlar; } \\
\text { a) I. Kademe (Yardımcı Antrenör): Üst } \\
\text { düzey antrenörün yanında ve spora yeni } \\
\text { başlayanlarda, } \\
\text { b) II. Kademe (Antrenör): Minikler ve } \\
\text { yıldızlar kategorisinde, } \\
\text { c) III. Kademe (Kıdemli Antrenör): Gençler } \\
\text { ve büyükler kategorisinde, } \\
\text { d) IV. Kademe (Başantrenör): Büyükler ve } \\
\text { milli takımlarda, } \\
\text { e) V. Kademe (Teknik Direktör): Büyükler } \\
\text { ve milli takımlarda Üst kademedeki } \\
\text { antrenör lisansına sahip olanlar alt } \\
\text { kademelerde de görev alabilirler. İlgili spor } \\
\text { dalında üst kademe antrenör bulunmaması } \\
\text { halinde bir alt kademedeki antrenör } \\
\text { görevlendirilebilir. }\end{array}$ & 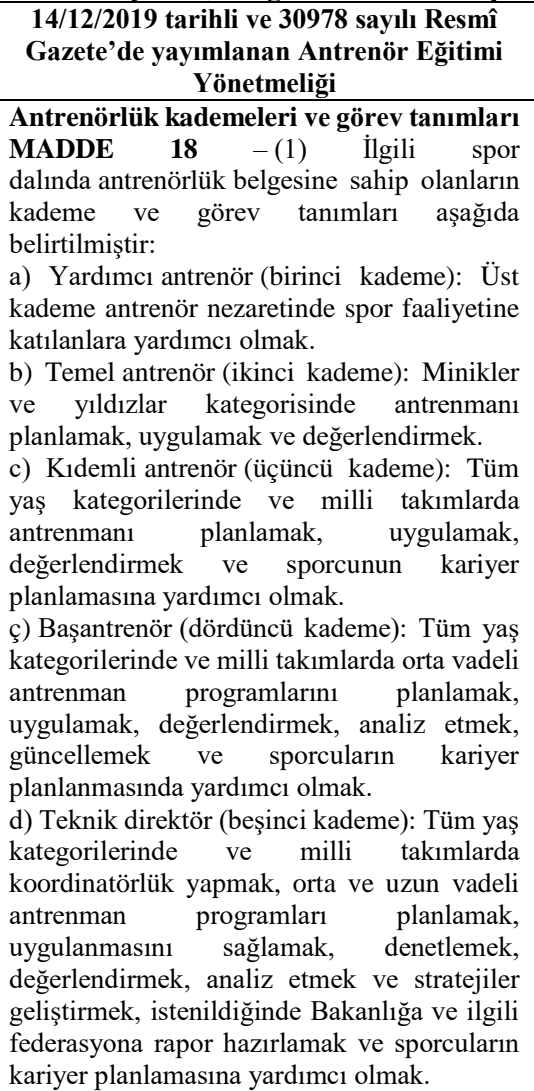 & $\begin{array}{l}\text { Bu madde kapsamında mülga } \\
\text { Yönetmelikten farklı olarak antrenörlere } \\
\text { nitelikli görevler yüklenmiştir. } \\
\text { - Kıdemli antrenörlüğe; tüm yaş } \\
\text { kategorilerinde antrenörlük yapmayı, } \\
\text { - Başantrenörlüğe; tüm yaş } \\
\text { kategorilerinde ve milli takımlarda } \\
\text { antrenörlük yapmayı, } \\
\text { - Teknik direktörlüğe; tüm yaş } \\
\text { kategorilerinde ve milli takımlarda } \\
\text { antrenörlük ve koordinatörlük } \\
\text { yapmayı, } \\
\text { görev tanımlarına eklenmiştir. } \\
\text { Mülga Yönetmelikte milli takımlarda } \\
\text { görev alabilme yalnızca 4. ve } 5 \text {. } \\
\text { kademedeki antrenörlere tanınırken } \\
\text { yürürlükteki Yönetmelik ile } 3 \text {. kademe } \\
\text { kıdemli antrenörlere de milli takımlarda } \\
\text { görev alma imkanı verilerek özellikle } \\
\text { antrenör havuzu eksik olan federasyonlar } \\
\text { için bu mağduriyet giderilmeye } \\
\text { çalışılmıştır. Ayrıca 3. 4. ve } 5 \text {. } \\
\text { kademelerdeki antrenörlere sporcuların } \\
\text { kariyer planları için yardımcı olma } \\
\text { görevi bu madde ile verilmiştir. }\end{array}$ \\
\hline
\end{tabular}


Özbey, Ö., Akoğlu, H.E. ve Donuk, B. (2020). Antrenör eğitim sistemi açısından 30978 sayılı Antrenör Eğitimi Yönetmeliği’nin değerlendirilmesi. Spor Bilimleri Araştırmaları Dergisi, 5(1), 95-110.

Tablo 3(Devamı). Antrenörlük kademeleri, kademelerin görev tanımları, geçiş işlemleri, hak ve muafiyetler, belge verilmesi ve iptali

\begin{tabular}{l} 
6/8/2002 tarihli ve 24848 sayılı Resmî \\
Gazete'de yayımlanan Antrenör Eğitim \\
Yönetmeliği \\
\hline Eğitim Kademeleri \\
Madde 9 - Antrenör eğitim kursları bütün \\
spor dalları için (V) kademede yapılır. \\
a) I.Kademe (Yardımcı Antrenör): Bu \\
kademe için düzenlenen eğitim programını \\
kapsar. \\
b) II. Kademe (Antrenör): I. kademe temel \\
çalıştırıcı (monitör) lisansına sahip ve en az \\
1 yıl üst kademe antrenörün yanında \\
çalışmış olduğunu belgeleyen antrenörlerin \\
katılabildiği eğitim programını kapsar. \\
c) III. Kademe (Kıdemli Antrenör) : II. \\
kademe antrenör lisansına sahip ve II. \\
kademede en az 2 yıl çalışmış olduğunu \\
belgeleyen ve bu süre içerisinde sporla \\
ilgili en az 2 seminer görmüş antrenörlerin \\
katılabildiği eğitim programını kapsar. \\
d) IV. Kademe (Başantrenör): III. kademe \\
antrenör lisansına sahip ve III. kademede \\
en az 3 yıl çalışmış olduğunu belgeleyen ve \\
bu süre içerisinde sporla ilgili en az 3 \\
seminer görmüş antrenörlerin katılabildiği \\
eğitim programını kapsar. \\
e) V. Kademe (Teknik Direktör): IV. \\
kademe antrenör lisansına sahip ve IV. \\
kademede en az 3 yıl çalışmış olduğunu \\
belgeleyen ve bu süre içerisinde sporla \\
ilgili en az 4 seminer görmüş antrenörlerin \\
katılabildiği eğitim programını kapsar. \\
\end{tabular}

\footnotetext{
Üniversitelerin Beden Eğitimi veya Spor

Eğitimi Veren Yüksek Öğrenim

Kurumlarından Mezun Olanlar

Madde 20 - Üniversitelerin beden eğitimi

veya spor eğitimi veren yüksek öğrenim kurumlarından mezun olup herhangi bir spor dalında ihtisas eğitimi almayan ancak bir spor dalında seçmeli olarak eğitim alanlara, o dalda, I. Kademe (Yardımcı Antrenör) antrenörlük belgesi verilir.

Üniversitelerin beden eğitimi veya spor eğitimi veren yüksek öğrenim

kurumlarından mezun olanlardan eğitim gördükleri spor dalındaki ihtisasları ile ilgili olarak durumlarını belgelemeleri şartıyla seçmeli (uzmanlık) spor dalında II. Kademe (Antrenör) antrenör belgesi verilir.

Üniversitelerin beden eğitimi veya spor eğitimi veren yüksek öğrenim kurumlarının antrenör eğitimi bölümü mezunlarına III. Kademe (Kıdemli Antrenör) antrenör belgesi verilir. III. Kademe (Kıdemli Antrenör) antrenör belgesini aldıktan sonra 3 yıl boyunca antrenörlük yaptığını ve ilgili spor dalında en az 2 seminere katıldığını belgeleyenlere, bașvurusu halinde IV. Kademe (Başantrenör) antrenör belgesi doğrudan verilir.
}

\section{4/12/2019 tarihli ve 30978 sayılı Resmî \\ Gazete'de yayımlanan Antrenör Eğitimi Yönetmeliği}

Antrenör eğitim programı kademeleri

arasında geçiş işlemleri

MADDE 19 (1) Temel eğitim sınavına katılıp bașarılı olan adaylar için temel eğitim sınav sonuçlarının geçerlilik süresi dört yıldır. Adaylar, temel eğitim sınav sonuçları geçerlilik süresi boyunca aynı kademedeki uygulama eğitimine ve daha alt kademedeki uygulama eğitimine katılabilir.

(2) Adayların herhangi bir kademedeki uygulama eğitimine katılabilmeleri için ilgili kademe veya daha üst kademedeki temel eğitimi tamamlayarak yapılacak sınavda başarılı olmaları gerekir.

(3) Uygulama eğitimi;

a) Yardımcı antrenör (birinci kademe) uygulama eğitimi; birinci kademe temel eğitimi tamamlayarak yapılacak sınavda başarılı olup antrenörlüğe başlayacaklara,

b) Temel antrenör (ikinci kademe) uygulama eğitimi; yardımcı antrenörlük belgesine sahip, belge tarihi üzerinden en az bir y1l geçen antrenörlere,

c) Kıdemli antrenör (üçüncü kademe) uygulama eğitimi; temel antrenörlük belgesine sahip, belge tarihi üzerinden en az iki yıl geçen ve temel antrenörlük belgesine sahip olduktan sonra en az iki gelişim seminerine katıldığını belgeleyen antrenörlere,

ç) Başantrenör (dördüncü kademe) uygulama eğitimi; k1demli antrenörlük belgesine sahip, belge tarihi üzerinden en az iki yıl geçen ve kıdemli antrenörlük belgesine sahip olduktan sonra en az iki gelişim seminerine katıldığını belgeleyen antrenörlere,

d) Teknik direktör (beșinci kademe) uygulama eğitimi; başantrenörlük belgesine sahip, belge tarihi üzerinden en az iki yıl geçen ve başantrenörlük belgesine sahip olduktan sonra en az iki gelişim seminerine katıldığını belgeleyen antrenörlere, yönelik düzenlenen eğitimdir.

Üniversitelerin spor bilimleri alanı lisans
eğitimi mezunları hak ve muafiyetleri MADDE 20 -(1) Üniversitelerin spor bilimleri alanında lisans eğitimi veren fakülte veya yüksekokullarının antrenörlük eğitimi bölümü/programı mezunlarının hak ve muafiyetleri aşağıdaki gibidir:

a) İlgili spor dalını ihtisas/uzmanlık olarak aldığını belgeleyenler, temel eğitim ve sınavından muaf olup, uygulama eğitimi ve sınavına katılarak başarılı olmaları halinde kıdemli antrenörlük belgesi almaya hak kazanır.

b) İhtisas/uzmanlık spor dalı haricinde en az bir dönem eğitim alanlar, tercih edeceği yalnızca bir spor dalında yardımcı antrenörlük belgesi almaya hak kazanır.

c) $\mathrm{Bu}$ fikra kapsamındakiler, mezuniyet tarihinden itibaren dört yıl boyunca kıdemli antrenörlük ve temel antrenörlük kademelerindeki temel eğitim ve sınavlarından muaftır.

\section{Değișikliklerin Gerekçesi}

$\mathrm{Bu}$ madde ile sınavların geçerlilik süreleri sabitlenmiş olup adayların hangi kademedeki eğitimlere başvuracakları açıkça belirtilmiştir.

Ayrıca mülga Yönetmelikte belirtilmiş; "...çalışmış olduğunu belgeleyen" ve "... sporla ilgili en az ... seminer görmüş" gibi müphem konulara yürürlükteki Yönetmelik ile açıklık getirilerek net ifadelere yer verilmiştir.
Üniversitelerin spor bilimleri alanında lisans eğitimi veren fakülte veya yüksekokullarından mezun olanlara, mülga Yönetmelik ile herhangi bir kriter aranmadan kişilerin mezun olduğu bölümlere göre çeşitli kademelerde antrenör belgesi verildiği görülmektedir. Bu durumun bir çok dezavantajı olmakla birlikte en belirgin olanlarl; ülkemizde bu eğitimleri veren okulların tümünde standart spor dalı alanı/salonu olmaması, akademisyenler arasındaki bilgi ve tecrübe farklılığı ve tüm öğrencilerin bütün dersleri takip edememesinden kaynaklı eksik bilgi edinmeleri gibi nedenlerden dolayı mezun olan kişiler, ilgili federasyona başvurmaları halinde federasyon tarafindan açılacak uygulama eğitim ve sınavlara girip bașarılı olmaları halinde mezuniyet durumlarına göre antrenör belgesi almaya hak kazanmaları hükmü getirilmiștir. 
Özbey, Ö., Akoğlu, H.E. ve Donuk, B. (2020). Antrenör eğitim sistemi açısından 30978 sayılı Antrenör Eğitimi Yönetmeliği’nin değerlendirilmesi. Spor Bilimleri Araştırmaları Dergisi, 5(1), 95-110.

Tablo 3(Devamı). Antrenörlük kademeleri, kademelerin görev tanımları, geçiş işlemleri, hak ve muafiyetler, belge verilmesi ve iptali

\section{6/8/2002 tarihli ve 24848 sayılı Resmî \\ Gazete'de yayımlanan Antrenör Eğitim} Yönetmeliği

\section{4/12/2019 tarihli ve 30978 sayılı Resmî Gazete'de yayımlanan Antrenör Eğitimi Yönetmeliği}

(2) Üniversitelerin spor bilimleri alanında lisans eğitimi veren fakülte veya yüksekokullarının antrenörlük eğitimi bölümü dışında kalan mezunlardan;

a) İlgili spor dalında en az iki dönem eğitim aldığını belgeleyenler, temel eğitim ve sınavından muaf olup, tercih edeceği yalnızca bir spor dalında ilgili federasyon tarafından açılan uygulama eğitimi ve sınavına katılarak başarılı olmaları halinde temel antrenörlük belgesi almaya hak kazanır. b) İlgili spor dalında en az bir dönem eğitim alanlar, tercih edeceği yalnızca bir spor dalında yardımcı antrenörlük belgesi almaya hak kazanır.

c) $\mathrm{Bu}$ fikra kapsamındakiler, mezuniyet tarihinden itibaren dört y1l boyunca temel antrenörlük temel eğitimi ve sinavından muaftır.

(3) Üniversitelerin spor bilimleri alanında lisans eğitimi veren fakülte veya yüksekokullarından lisans mezunu olanlar, tüm spor dallarında yardımcı antrenörlük temel eğitim ve sinavindan muaftır.

(4) Üniversitelerin spor bilimleri alanında yüksekokullarından çift ana dal mezunu olanlar, bu maddenin birinci ve ikinci fikraları hükümlerine istinaden, her bir ana dal için ayrı ayrı olmak üzere ilgili spor dalında durumlarına uygun antrenörlük belgesi almaya hak kazanır.

Başarılı sporcu ve antrenörlerinin hak ve muafiyetleri

MADDE $22 \quad$-(1) Sporculardan; Olimpiyat, paralimpik, deaflimpik ve dünya şampiyonlarında başarılı oldukları spor dalında başarılarına göre ilgili kademelerde antrenör eğitim programına katılmaya hak kazanır. (Maddenin devamı için ilgili yönetmeliğe bakınız) lisans eğitimi veren fakülte veya

\section{Değişikliklerin Gerekçesi}

Ayrıca üniversitelerin spor bilimleri alanında lisans eğitimi veren fakülte veya yüksekokullarından mezun olanlara mülga Yönetmelikte olmayıp yürürlükte olan Yönetmelik ile herhangi bir eğitime ve sinava katılmadan ikinci bir belge alma imkanı sağlanmıştır.

Yine lehte bir uygulama ile bu okullardan mezun olanlara mezuniyet tarihlerinden itibaren dört yll boyunca hak ettikleri seviyedeki antrenörlük kademelerindeki diğer branşların temel eğitim ve sınavlarından muafiyet hakkı tanınmıştır.

Bu maddenin bir ile dördüncü fikralarında geçen ibarelerle sporculara başarılı oldukları derecelere göre haklar verilmiștir. Ayrıca sporculara bu fikralar ile başarılı olup çeşitli nedenlerle aktif sporculuğu bırakmaları neticesinde kişilere spordan ayrılmadan kariyer planlarını yapabilme imkanı sağlanmıştır. $\mathrm{Bu}$ sayede başarılı sporcular gerekli antrenörlük eğitimlerini alarak sporculuk yaşamlarında sahip oldukları bilgi ve tecrübelerinden antrenör olarak yararlanılması amaçlanmıştır.

$\begin{array}{llll}\begin{array}{l}\text { Ortaöğretim mezunlarının hak ve } \\ \text { muafiyetleri }\end{array} & \end{array}$

MADDE 23 - (1) Spor liselerinden mezun olanlara eğitim gördüğü yalnızca bir spor dalında, diğer ortaöğretim kurumlarından mezun olanlara ise ders müfredatlarının temel eğitim derslerine uygunluğu halinde yalnızca eğitim gördüğü bir spor dalında yardımcı antrenörlük belgesi almaya hak kazanır. 
Özbey, Ö., Akoğlu, H.E. ve Donuk, B. (2020). Antrenör eğitim sistemi açısından 30978 sayıllı Antrenör Eğitimi Yönetmeliği’nin değerlendirilmesi. Spor Bilimleri Araştırmaları Dergisi, 5(1), 95-110.

Tablo 3 (Devamı). Antrenörlük kademeleri, kademelerin görev tanımları, geçiş işlemleri, hak ve muafiyetler, belge verilmesi ve iptali

6/8/2002 tarihli ve 24848 sayılı Resmî
Gazete'de yayımlanan Antrenör Eğitim
Yönetmeliği

\section{4/12/2019 tarihli ve 30978 sayılı Resmî \\ Gazete'de yayımlanan Antrenör Eğitimi Yönetmeliği}

\section{Antrenörlük belgesi}

MADDE 24 - (1) Antrenörlük belgesi;

a) Antrenörlük eğitim programını

tamamlayarak yapılacak sınavlarda başarılı olanlara,

b) Üniversitelerin spor bilimleri alanında lisans eğitimi veren fakülte veya yüksekokullarından mezun olanlara, Konservatuarı, Devlet Konservatuarı Türk Halk Oyunları Bölümü ve Modern Dans Bölümü lisans mezunu olanlara,

ç) 23 üncü maddedeki şartları sağlayanlara, ilgili federasyona başvurmaları ve 7 nci maddede yer alan șartları taşımaları kaydıyla Bakanlık onayı ile verilir. c) Üniversitelerin Türk Musikisi Devlet

\section{Değişikliklerin Gerekçesi}

Antrenör belgeleri 14/12/2019 tarihine kadar;

1)Gençlik ve Spor Bakanlığı Spor Eğitimi Dairesi Başkanlığı ile iş birliği içinde antrenör yetiștirme kursu açan federasyonlar, belge düzenlenme sürecini de Spor Eğitimi Dairesi Başkanlığı ile birlikte yürütmekteydi.

2)Spor Eğitimi Dairesi Başkanlığı ile iş birliği içinde antrenör yetiștirme kursu açmayan federasyonlar ise tüm işlemleri kendi bünyelerinde yürütmekteydi 3)Üniversitelerin spor bilimleri alanında lisans eğitimi veren fakülte veya yüksekokullarından mezun olanlara; Spor Eğitimi Dairesi Başkanlığınca BESYO Mezunları Denklik Isslemleri ile kademeleri itibariyle mezunlara belge düzenlenmekteydi.

Yeni Yönetmelik ile bu farklılıklar ortadan kaldırılmış olup usulde ve uygulamada birlik sağlanmıştır.

Yurt Dışından Alınan Antrenörlük
Belgelerinin Denkliği
Madde 23 - Yurt dışından alınan
belgelerin bu Yönetmelikte belirtilen
kademelere göre denkliği; bu Yönetmeliğin
10 uncu maddesindeki eğitim programı esas
alınarak yurt dışında katıldığı kursları başarı
ile tamamladıklarını belgelemeleri halinde
ilgili federasyon yönetim kurulunun görüşü
ile birlikte Daire Başkanlığının teklifi ve
Genel Müdürlük Makamının onayı ile ilgili
spor dalına ait, durumuna uygun antrenör
belgesi verilir.

Antrenörlük belgesi denklik işlemleri
MADDE $25 \quad-(1) \quad$ Yurtdışından
alınan antrenörlük belgelerinin renklik
işlemleri; ilgili federasyonun bağlı olduğu
uluslararası federasyon veya federasyonlar
birliği tarafından tanınan uluslararası kurum
ve kuruluşlardan alınan antrenörlük
belgelerinin denklik işlemleri; federasyon
eğitim kurulunun gerekçeli teklifi, yönetim
kurulunun kararı ve Bakanlığın uygun görüşü
üzerine, uygun kademedeki uygulama eğitimi
ve sınavında başarılı olunması
şartıyla takdiren gerçekleştirilir.
$\mathrm{Bu}$ maddenin birinci fikrasında yurtdışından alınan belge geçerliliğinin doğrulanabilmesi için ilgili federasyonun bağlı olduğu uluslararası federasyon veya federasyonlar birliği tarafından tanınan uluslararası kurum ve kuruluşlardan alınması şartı getirilmiştir.

Haricinde ilgili federasyon tarafindan yapılacak sınavla bu kişilerin antrenörlük nitelikleri yeniden gözden geçirilmesi hedeflenmektedir.

Tablo 3'te 6/8/2002 tarihli ve 24848 sayılı Resmî Gazete'de yayımlanan mülga Antrenör Eğitim Yönetmeliği ile 14/12/2019 tarihli ve 30978 sayılı Resmî Gazete'de yayımlanan Antrenör Eğitimi Yönetmeliğinin üçüncü bölümü olan “Antrenörlük Kademeleri, Kademelerin Görev Tanımları, Geçiş İşlemleri, Hak ve Muafiyetler, Belge Verilmesi ve İptali” bölümünün karşılaştırılması yapılmış ve yapılan değişikliklerin gerekçeleri gösterilmiştir.

Tablo 4. Çeşitli ve son hükümler

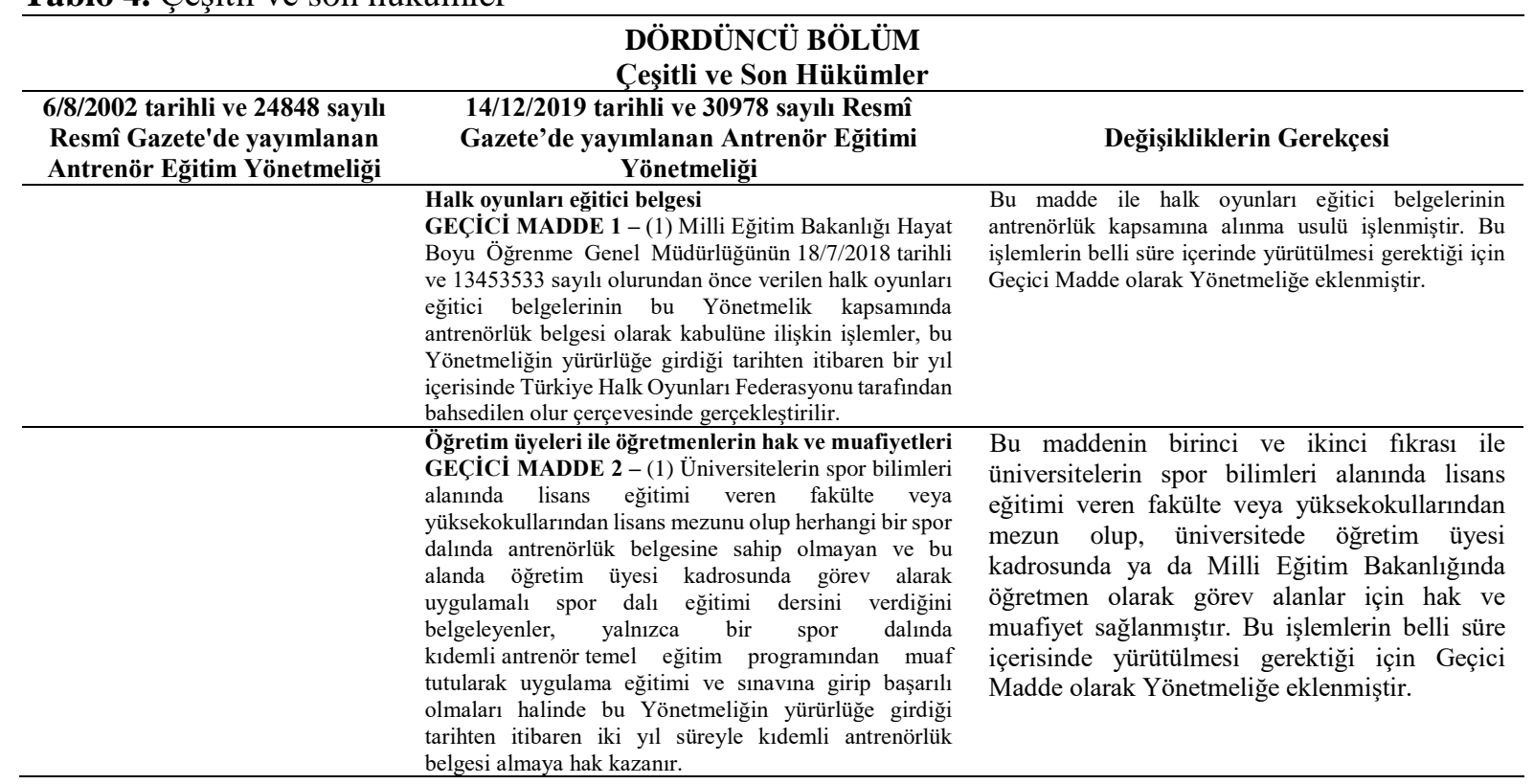




\begin{tabular}{|c|c|c|}
\hline \multirow[t]{3}{*}{$\begin{array}{l}\text { 6/8/2002 tarihli ve } 24848 \text { sayılı } \\
\text { Resmî Gazete'de yayımlanan } \\
\text { Antrenör Eğitim Yönetmeliği }\end{array}$} & $\begin{array}{l}\text { 14/12/2019 tarihli ve } 30978 \text { sayılı Resmî } \\
\text { Gazete'de yayımlanan Antrenör Eğitimi } \\
\text { Yönetmeliği }\end{array}$ & Değişikliklerin Gerekçesi \\
\hline & $\begin{array}{l}\text { (2) Üniversitelerin spor bilimleri alanında lisans } \\
\text { eğitimi veren fakülte veya yüksekokullarından } \\
\text { mezun olup Milli Eğitim Bakanlığında öğretmen } \\
\text { olarak istihdam edilenler, eğitim gördükleri } \\
\text { uzmanlık/ihtisas dersi ile ilgili olarak durumlarını } \\
\text { belgelemeleri şartıyla temel eğitim programından } \\
\text { muaf tutularak uygulama eğitimi ve sınavina girip } \\
\text { başarılı olmaları halinde bu Yönetmeliğin } \\
\text { yürürlüğe girdiği tarihten itibaren iki yıl süreyle } \\
\text { bir uzmanlık/ihtisas spor dalında } \\
\text { temel antrenörlük belgesi almaya hak kazanır. }\end{array}$ & \\
\hline & $\begin{array}{l}\text { Diğer geçiş hükümleri } \\
\text { GEÇiCí MADDE } \mathbf{3}-(1) \text { Federasyonlar, bu } \\
\text { Yönetmeliğin yürürlüğe girdiği tarihten itibaren } \\
\text { üç ay içerisinde antrenör eğitim talimatlarını bu } \\
\text { Yönetmelik hükümlerine uygun hale getirir. } \\
\text { (2) Bu Yönetmeliğin yürürlüğe girdiği tarihten } \\
\text { önce başlamış olan işlemler, yürürlükten } \\
\text { kaldırılan Yönetmelik hükümlerine göre } \\
\text { sonuçlandırlır. }\end{array}$ & $\begin{array}{l}\text { Federasyonlar tarafindan mülga Yönetmelik } \\
\text { hükümlerine göre dayanılarak hazırlanan } \\
\text { antrenör eğitim talimatlarının belirtilen süre } \\
\text { içerisinde revize edilmesi istenmiş ve } \\
\text { Yönetmeliğin yürürlüğe girdiği 14/12/2019 } \\
\text { tarihinden önce başlamış olan işlemler, } \\
\text { yürürlükten kaldırılan Yönetmelik hükümlerine } \\
\text { göre sonuçlandırılması ile federasyonların ve } \\
\text { kişilerin herhangi bir mağduriyet yaşaması } \\
\text { engellenmiştir. Bu işlemlerin belli süre içerinde } \\
\text { yürütülmesi gerektiği için Geçici Madde olarak } \\
\text { Yönetmeliğe eklenmiştir. }\end{array}$ \\
\hline
\end{tabular}

Tablo 4'de 6/8/2002 tarihli ve 24848 sayılı Resmî Gazete'de yayımlanan mülga Antrenör Eğitim Yönetmeliği ile 14/12/2019 tarihli ve 30978 sayılı Resmî Gazete'de yayımlanan Antrenör Eğitimi Yönetmeliğinin dördüncü bölümü olan "Çeşitli ve Son Hükümler" bölümünün karşılaştırılması yapılmış ve yapılan değişikliklerin gerekçeleri gösterilmiştir.

\section{TARTIŞMA VE SONUÇ}

Bu çalışmada kamu ya da özel sektör fark etmeksizin kurumsal imajı ve sürdürülebilir başarıyı sağlamak için önemli bir rol üstlenen antrenörlerin yetiştirilmesi için Gençlik ve Spor Bakanlığı tarafından yaklaşık 18 yıl arayla çıkarılan iki yönetmeliğin karşılaştırılması ve yeni çıkarılan Yönetmelik ile yürütülmek istenen antrenör eğitim sistemi incelenmiştir.

Ülkemizde resmi kayıtlara göre yaklaşık 278 bin antrenör bulunmakta ve Gençlik ve Spor Bakanlığ1 bünyesinde farklı statülerde istihdam edilen yaklaşık 5 bin antrenör görev yapmaktadır (shgm.gsb.gov.tr/). Kurum politikaları incelendiğinde merkez ve taşra teşkilatlanmasının revize edilerek daha kurumsal bir yapıya dönüştüğü (gsb.gov.tr/) ve taşra teşkilatında istihdam edilmek üzere antrenör alımlarının belirli aralıklarla yapıldığı görülmektedir. Tüm bu sebeplerden dolayı mevcutta görev alan ve gelecek yıllarda istihdam edilmesi düşünülen antrenörler için güncel, sistemli ve kapsamlı bir eğitim programının gerekliliğinden dolayı revise edilen Antrenör Eğitimi Yönetmeliği 14/12/2019 tarihli ve 30978 sayılı Resmî Gazete'de yayımlanarak yürürlüğe girmiştir (Resmi Gazete, 2019). Yeni yayımlanan Yönetmelik; birçok üniversite, spor federasyonları, kamu kurum ve kuruluşu ile ilgili paydaşların görüşleri alınarak hazırlanmıştır. Yürürlükteki Yönetmelikte yapılan başlıca değişiklikler şu şekilde ortaya konmuştur:

- Anayasada yer alan 59 uncu madde hükmü "Devlet, her yaştaki Türk vatandaşlarının beden ve ruh să̆lı̆̆ını geliştirecek tedbirleri alır, sporun kitlelere yayılmasını teşvik eder." şeklindedir (Anayasa, 1981). Son çıkarılan Antrenör Eğitimi Yönetmeliğinin amacına da mülga Yönetmelikten farklı olarak performans ve rekreatif katılım eklenmiş ve yalnızca sporcular değil her yaştaki bireylerin eğitimine de atıfta bulunulmuştur. 
- İlk resmi antrenörlük kursu Türk Spor Kurumu tarafından 1938 yılında düzenlenmiş olup, bu kurslar çeşitli şekillerde uygulanmaya devam etmiştir. Yürürlükte olan Yönetmelik ile usulde ve uygulamada birlik sağlanarak antrenör yetiştirilmesi ile ilgili tüm iş ve işlemler tek çatı altına alınmış ve Yönetmelik kapsamına dahil edilmiştir.

- Adaylarda aranılan şartlar incelendiğinde mülga Yönetmelikte milli sporculardan tahsil şartı aranmaz ibaresi kaldırılmış ve adayların belli bir eğitim seviyesinde olma şartı getirilmiştir. Ayrıca yürürlükteki Yönetmelik ile federasyonlara, antrenör eğitimi talimatlarında ilgili spor dalınının özelliklerine göre sağlık şartları ve yaş sınırları gibi özel şartlarını belirleme imkanı verilmiştir.

- Yeni antrenör eğitim programı, teorik derslerin yer aldığı temel eğitim ile spor dallarının özelliğine göre uygulama eğitimi olarak iki aşamalı gerçekleştirilecektir. Temel eğitim, uzaktan eğitim yöntemiyle Bakanlık tarafından yetkilendirilecek eğitim kurumu aracılığıyla beş kademe olarak düzenlenecektir. Bu değişiklik ile ülkemizde gelişen teknoloji ve altyap1 sayesinde antrenör adaylarına temel eğitime erişilebilirliği yaygınlaştırılacak, eğitimde firsat eşitliği sunulacak, eğitimlerin kalite standardizasyonunu ülke genelinde tüm adaylar için eşit ve adil bir şekilde sağlanabilecektir. Uygulama eğitimine ilişkin düzenlemeler ile bu eğitiminin sevk ve idaresi ise 3289 sayılı Gençlik ve Spor Hizmetleri Kanunu kapsamında kurulan spor federasyonları ve Bakanlık ile iş birliği içerisinde hazırlanacak olan ilgili spor dalı federasyonlarının antrenör eğitim talimatlarında belirtilecektir. Yücel ve Devecioğlu (2012) yaptıkları araştırmada beden eğitimi alanında teknoloji kullanımı hem teorik bilgilerin hem de psikomotor becerilerin öğretilmesinde, öğretmen-öğrenci etkileşimini ve motivasyonu artırıc1 bir unsur olduğunu ifade etmişleridir. Spor sektörü inovasyon, yaratıcı fikirler ve teknolojinin yeni trendlerinin gelişimine açık bir alan olduğundan (Donuk, 2019) ve antrenörlük eğitimi yalnızca üniversitelerin spor bilimleri alanında lisans eğitiminde değil uzaktan eğitim aracılığıyla üniversitelerin dışında da antrenör adaylarının eğitim alabilmelerinin gerekmesinden bahsedilmektedir (Ziyagil ve Sevimli, 2013). Sunay’ın (1997) yılında yapmış olduğu bir araştırmada, antrenör kurslarına katılan adaylar eğitim programında yer alan uygulama derslerinin fayda sağladığını ancak temel eğitim programında yer alan derslerin daha az fayda sağladığını belirtmiştir. Bu nedenle yeni uygulama sayesinde ülke genelinde usulde ve uygulamada birliğin sistemsel olarak yürütülmesinin faydalı olacağı düşünülmektedir.

- Öğretim elemanlarının görevlendirilmelerinde özellikle yeni kurulan federasyonlar tarafından uygulanması mümkün olmayan mülga Yönetmelikteki “Özel eğitim programına ait derslerin ögreticileri ilgili spor dalında; ihtisas sahibi öğretim elemanı unvanına sahip olanlar ile IV. Kademe (Başantrenör) veya V. Kademe (Teknik Direktör) antrenör belgesine sahip olan kişiler arasından ilgili federasyonca seçilir." maddesi işlevsel hale getirilerek 4. ve 5. kademe şartı kaldırılmış, kademe belirtilmeden açılacak eğitim kademesine göre üst ya da denk kademe antrenörlerin uygulama eğitimlerini vermeleri hükmü getirilmiştir. Yine işlevsellik açısından ilgili spor dalında antrenör olmaması halinde spor uzmanı, yabancı spor uzmanı veya yabanc1 antrenör görevlendirilebileceği hükmü eklenmiştir.

- Uygulama eğitimi sınav kurulu ve komisyonları ile ilgili madde ile eğitimler ve sınavlar federasyonlar tarafından oluşturulacak komisyon tarafından yürütülecektir. Bu şekilde eğitim ve sinavda belirli bir kalite yakalanacak, olası itirazlar sınav komisyonu ve kurul tarafindan değerlendirilecektir. Mülga Yönetmelikte adaylar sınavlara kurs bitiminden sonra 30 gün 
içerisinde itiraz edebilmekte ve 30 gün içerisinde de ilgili Daire Başkanlığından yanıt verilmekteyken, yürürlükte olan Yönetmelik ile sınav sonuçlarının açıklanmasından sonra 5 gün içerisinde itiraz edilebilmekte ve 15 gün içerisinde itirazların incelenerek karara bağlanması kararlaştırılmıştır. Bu şekilde eğitim ve sınavda belirli bir kalite yakalanacak, olası itirazlar sınav komisyonu ve kurul tarafından değerlendirilecektir.

- Müsabakası yapılmayan ve antrenörlük kapsamı dışında kalan her türlü rekreatif amaçlı fiziksel ve zihinsel egzersizleri içeren eğitim programlarının uygulanmasında görev alan kişilerin eğitimleri ve görev alanları ile ilgili usul ve esasların düzenlenmesi maddesi ile antrenör ve eğitmenin görev alanları ayrılmış ve kişilerin hangi hallerde eğitmen olabileceği netleştirilmiştir. Temel ayrım müsabakası yapılmayan ve antrenörlük kapsamı dışında kalan her türlü rekreatif amaçlı fiziksel ve zihinsel egzersizleri yaptıracak kişilerin eğitimleri ve görev alanları olarak düzenlenmiştir.

- Antrenörlük kademeleri ve görev tanımları güncel ihtiyaçlar ve gereksinimler doğrultusunda revize edilerek mülga Yönetmelikten farklı olarak antrenörlere nitelikli görevler yüklenmiştir. Kıdemli antrenörlüğe; tüm yaş kategorilerinde antrenörlük yapma, başantrenörlüğe; tüm yaş kategorilerinde ve milli takımlarda antrenörlük yapma, teknik direktörlüğe; tüm yaş kategorilerinde ve milli takımlarda antrenörlük ve koordinatörlük yapma görevini vermiştir. Bir diğer faklı görev ise mülga Yönetmelikte milli takımlarda görev alabilme yalnızca 4. ve 5. kademedeki antrenörlere tanınırken yürürlükteki Yönetmelik ile 3. kademe kıdemli antrenörlere de milli takımlarda görev alma imkanı verilerek özellikle antrenör havuzu eksik olan federasyonlar için bu mağduriyet giderilmeye çalışılmıştır. Ayrıca 3., 4. ve 5. kademelerdeki antrenörlere sporcuların kariyer planları için yardımcı olma görevini de bu madde ile verilmiştir.

- Üniversitelerin spor bilimleri alanında lisans eğitimi veren fakülte veya yüksekokullarından mezun olanlara mülga Yönetmelik ile herhangi bir kriter aranmadan kişilerin mezun olduğu bölümlere göre çeşitli kademelerde antrenör belgesi verilmekteydi. Bu durumun bir çok dezavantajı olmakla birlikte en belirgin olanları; ülkemizde bu eğitimleri veren okulların tümünde standart spor dalı alanı/salonu olmaması, akademisyenler arasındaki bilgi ve tecrübe farklılığı ile tüm öğrencilerin bütün dersleri takip edememesinden (öğrencilerin ortalama 4 ders devamsızlık hakkı ve sağlık raporu alarak derse katılamama, resmi tatiller gibi nedenler) kaynaklı eksik bilgi edinmeleri gibi nedenlerden dolayı mezun olan kişiler, ilgili federasyona başvurmaları halinde federasyon tarafından açılacak eğitim ve sınavlara girip başarılı olmaları şartıyla mezuniyet durumlarına göre antrenör belgesi almaya hak kazanmaları hükmü getirilmiştir. Ayrıca üniversitelerin spor bilimleri alanında lisans eğitimi veren fakülte veya yüksekokullarından mezun olanlara mülga Yönetmelikte olmayıp, yürürlükte olan Yönetmelik ile herhangi bir eğitime ve sinava katılmadan ikinci bir belge (birinci kademe) alma imkanı sağlanmıştır. Yine lehte bir uygulama ile bahsedilen okullardan mezun olanlara, mezuniyet tarihlerinden itibaren dört yll boyunca hak ettikleri seviyedeki antrenörlük kademelerindeki temel eğitim ve sınavlarından muafiyet hakkı tanınmıştır. Ziyagil (2020)'in çalışmasında üniversitelerin antrenörlük bölümü mezunlarının mezun olduktan sonra merkezi bir sınav ile tekrar sınava girmelerini ve yeterli düzeyde olanların antrenör olması gerektiğini belirtmiştir.

- Başarılı sporcu ve antrenörlerinin hak ve muafiyetlerinin yer aldığ 22 nci maddenin bir ile dördüncü fıkralarında geçen ibarelerle sporculara başarılı oldukları derecelere göre haklar 
verilmiştir. Ayrıca sporculara bu fikralar ile başarılı olup çeşitli nedenlerle aktif sporculuğu bırakmaları sonrasında kişilere spordan ayırmadan kariyer planlarını yapabilme imkanı sağlanmıştır. Bu sayede başarılı sporcular gerekli antrenörlük eğitimlerini alarak sporculuk yaşamlarında edindikleri bilgi ve tecrübelerinden antrenör olarak yararlanılması amaçlanmıştır. Ayrıca altıncı fikrada sporcularının başarısından dolayı antrenörlere de hak ve muafiyetler tanınmış olup, Paralimpik ve Deaflimpik oyunlarında madalya alan sporculara ve antrenörlerine yalnızca kendi spor dallarında açılacak antrenör eğitim programlarında muafiyet sağlanması ile mülga Yönetmelikteki anlam karmaşası ortadan kaldırılmıştır.

- Ortaöğretim mezunlarının hak ve muafiyetleri ile ilgili olarak "Spor liselerinden mezun olanlara ĕ̌itim gördüğü yalnızca bir spor dalında, diğer ortaöğretim kurumlarından mezun olanlara ise ders müfredatlarının temel eğitim derslerine uygunluğu halinde yalnızca eğitim gördüğü bir spor dalında yardımcı antrenörlük belgesi almaya hak kazanır." şeklinde yeni Yönetmelikte yer almıştır. Milli Eğitim Bakanlığı tarafından Spor Lisesi müfredatı değiştirilerek antrenör temel eğitim derslerine entegrasyonu sağlanmıştır. 2019-2020 eğitim öğretim yılından başlamak üzere belirtilen eğitim dönemi ve sonrasında mezun olanlara eğitim gördügü yalnızca bir spor dalında yardımcı antrenörlük belgesi verilmesi hükmü getirilmiştir. $\mathrm{Bu}$ okullardan mezun olanlar hem antrenörlük mesleği ile genç yaşta tanışarak bu alanda hedefler oluşturacak hem de üniversitelerin spor bilimleri alanında lisans eğitimi veren fakülte veya yüksekokullarına herhangi bir lise mezunundan çok daha donanımlı bir şekilde girerek spor sektörüne katma değer sağlayacakları düşünülmektedir.

- Yurtdışından alınan antrenörlük belgelerinin denkliği ile ilgili maddede, önceki Yönetmelikte ilgili federasyon yönetim kurulunun görüşü ile birlikte Daire Başkanlığının teklifi ve Genel Müdürlük Makamının onayı ile ilgili spor dalına ait, durumuna uygun antrenör belgesi verilirken, yürürlükteki Yönetmelikle federasyon eğitim kurulunun gerekçeli teklifi, yönetim kurulunun kararı ve Bakanlığın uygun görüşü üzerine, uygun kademedeki uygulama eğitimi ve sınavında başarılı olunması şartıyla verileceği belirtilmiştir. Ayrıca yurtdışından alınan belge niteliğinin doğrulanabilmesi maksadı ile ilgili federasyonun bağlı olduğu uluslararası federasyon veya federasyonlar birliği tarafindan tanınan uluslararası kurum ve kuruluşlardan alınan belgelerin geçerlilik şartı getirilmiştir.

- Antrenör kursları 14/12/2019 tarihine kadar federasyonlar tarafindan ya da Spor Eğitimi Dairesi Başkanlığı ile işbirliği içinde yürütülmekteydi. Ayrıca tüm spor dallarında BESYO mezunları denklik işlemleri yine Spor Eğitimi Dairesi Başkanlığı tarafından yürütülmekteydi. Yeni Yönetmelik ile bu farklılıklar ortadan kaldırılmış olup usulde ve uygulamada birlik sağlanmıştır.

- Halk oyunları eğitici belgesi "Milli Ĕ̆itim Bakanlı̆̆l Hayat Boyu Öğrenme Genel Müdürlüğünün 18/7/2018 tarihli ve 13453533 sayll olurundan önce verilen halk oyunlart eğitici belgelerinin bu Yönetmelik kapsamında antrenörlük belgesi olarak kabulüne ilişkin işlemler, bu Yönetmeliğin yürürlüğe girdiği tarihten itibaren bir yıl içerisinde Türkiye Halk Oyunları Federasyonu tarafindan bahsedilen olur çerçevesinde gerçekleştirilir". Bu madde ile halk oyunları eğitici belgelerinin antrenörlük kapsamına alınma usulü işlenmiştir.

- Yürürlükte olan Yönetmeliğe yeni eklenen Geçici Madde 2 kapsamında, öğretim üyelerine ve öğretmenlere hak ve muafiyetler sağlanarak, üniversitelerin spor bilimleri alanında lisans 
eğitimi veren fakülte veya yüksekokullarından mezun olup üniversitede öğretim üyesi kadrosunda ya da Milli Eğitim Bakanlığında öğretmen olarak görev alanlar için bu madde düzenlenmiştir.

- Uluslararası federasyonlarında eğitim kriterleri göz önünde bulundurularak Bakanlık ve ilgili spor federasyonlarıyla iş birliği içerisinde düzenlenecek kurs, seminer ve benzeri eğitim faaliyetleri de antrenörlerin bilgilerinin artırılmasına ve güncellenmesine olanak sağlanmıştır.

- Yönetmeliğin sistemsel olarak en köklü değişikliklerinden birisi de temel eğitim derslerinin uzaktan eğitim metoduyla uygulanmasıdır. Özellikle tüm dünyayı etkisi altına alan Covid-19 salgını döneminde bu değişikliğin bir kez daha yerinde bir karar olduğunu görülmektedir. UNESCO, 27 Mart 2020 tarihi itibariyle 188 ülkede 1,5 milyardan fazla öğrencinin ve 63 milyon eğitimcinin Covid-19 salgını nedeniyle etkilendiğini açıklamıştır (UNESCO, 2020). 2020 Mart ayı içerisinde, pandeminin yol açtığı yüz yüze eğitimin sakıncaları sebebi ile örgün eğitim gören tüm öğrenciler için eğitime ara verilmiş ve eğitimlerin uzaktan eğitim yoluyla devam edilmesi yönünde Milli Eğitim Bakanlığı ve Yüksek Öğretim Kurumu tarafından karar alınmıştır (Telli Yamamoto ve Altun, 2020). Bu durum yalnızca ülkemizde değil birçok ülkede uygulamaya konulmuştur. Ülkeler, mevcut Covid-19 kitlesel sağl1k problemi konusunda tedbirler alarak tüm sektörlerde olduğu gibi eğitim sektöründe de öğrenenlerin zaman kaybetmemesi ve bilgi kaybı yaşamaması maksadıyla uzaktan eğitim sistemlerinin aktif hale getirilmesi kararını almıştır (OECD, 2020). Yeni düzenleme ile antrenörlere; zaman ve mekân sınırları ortadan kaldırarak elektronik ortamda bilgiye kolay erişilebilirliğin vermiş olduğu esneklik sayesinde kendilerinin belirleyecekleri saatte ve günde, 7/24 eşit bilgiye ulaşabilme imkanı sağlamaktadır. Bu faydalar göz önüne alındığında uzaktan eğitim metodu ile öğrenme bir zorunluluk değil aksine Devlet desteği ve gözetiminde; modern, etkili ve katma değeri yüksek, antrenörlerin çağa ayak uydurabilmeleri ve mesleki kariyerleri için en güncel bilgileri edinmeleri için önemli bir firsat olarak değerlendirilmektedir. Ayrıca, teorik derslerin senkron (eşzamanlı) ya da asenkron (eşzamanlı olmayan) olarak planlanması (Telli Yamamoto ve Altun, 2020), ders notlarının sunucu ağ platformu üzerinden sınırsız paylaşılması, açılacak eğitim ve sınavların belirli dönemlerde eğitim ve sınav takvimi olarak sabitlenmesi antrenör eğitim sistemine ve Bakanlığın kurumsal imajına pozitif değer kattığı düşünülmektedir.

Sonuç olarak mülga (eski, yürürlükten kaldırılan) Yönetmeliğe kıyasla yürürlükte olan (yeni çıkarılan, mevcutta olan) Yönetmeliğin birçok açıdan ülke sporunun ve toplum sağlığının geliştirilmesinde en önemli unsur olan antrenörlerin, beşeri sermaye açısından eğitim süreçleri ve mesleki gelişimleri için daha etkili olacağına, geçmiş uygulamadaki birçok müphemliğin ve aksaklığın giderilmesine yardımcı olacağı sonucuna varılmıştır. 


\section{ÖNERILER}

Yürürlükte olan Yönetmelik ile;

- Antrenör adaylarının 1. kademe yardımci antrenörlük süresi boyunca üst kademe antrenörlerin nezaretinde staj uygulaması görmeleri antrenörlerin tecrübe kazanmaları acısından yeni Yönetmelikte yer alabilirdi.

- 4. kademe ve 5. kademe antrenörler için belirli federasyonlar için, ilgili spor dalı içerisinde uzmanlaştığı alt branşları belgelerinde yer alması. Örnek vermek gerekirse; atletizm spor dalı için 4. kademe baş antrenör (atmalar) ya da 5. kademe teknik direktör (atlamalar) gibi kişilerin belgelerinde bu ayrım olabilirdi.

- Yönetmeliğin 7 nci maddesinde antrenör eğitim programına katılacak adaylarda aranılacak şartlara, 5. kademe teknik direktörlük için öğrenim şartının yüksek öğrenim şartı olarak istenebilirdi. Bu sayede antrenör eğitim sistemi içerisindeki en üst basamak ile ilk basamak arasında eğitim ve sınavların, gelişim seminerleri şatının, tecrübenin yanı sıra eğitim düzeylerinde de belirli fark sağlanabilirdi.

- Bu bilgiler 1şığında, yukarıda bahsedilen önerilere ek olarak;

Gençlik ve Spor Bakanlığı bünyesinde istihdam edilen her kademedeki antrenör için belirli süreyle teorik ve uygulamalı eğitimlerle mesleki güncel bilgiler edinebilecekleri ve var olan antrenörlük becerilerini geliştirebilecekleri “Antrenör Eğitim Merkezi” nin açılmasının antrenör gelişimi açısından faydalı olacağı düşünülmektedir.

Kurumsal olarak "Antrenörlük Mesleği Etik İlkeleri" nin belirlenmesinin gerektiği düşünülmektedir. Bu sayede çalışanlar, yazılı normlar haricinde etik olarak antrenörlüğün gerekliliklerini yerine getirirken negatif yöndeki kişisel eğilimlerini sınırlandıracağı, meslek içi rekabeti adil bir şekilde gerçekleştirileceği, kişisel ve dolayısıyla kurumsal itibarın korunacağı düşünülmektedir.

Yayın Etiği: Mevcut çalışmanın yazım sürecinde "Yükseköğretim Kurumları Bilimsel Araştırma ve Yayın Etiği Yönergesi” kapsamında bilimsel, etik ve alıntı kurallarına uyulmuş olup; toplanan veriler üzerinde herhangi bir tahrifat yapılmamış ve bu çalışma herhangi başka bir akademik yayın ortamına değerlendirme için gönderilmemiştir.

\section{KAYNAKLAR}

Antrenör Eğitim Yönetmeliği. (2002). T.C. Cumhurbaşkanlığı Resmi Gazete, 6/8/2002 tarihli ve 24848 sayıl1. [https://www.resmigazete.gov.tr/eskiler/2002/08/20020816.htm\#2], Erişim Tarihi: 10 Nisan 2020.

Antrenör Eğitimi Yönetmeliği (2019). T.C. Cumhurbaşkanlığg Resmi Gazete, 14/12/2019 tarihli ve 30978 sayıll, [https://www.resmigazete.gov.tr/eskiler/2019/12/20191214-2.htm], Erişim Tarihi: 10Nisan 2020.

Conroy, D.E. \& Coatsworth, J.D. (2006). Coach training as a strategy for promoting youth social development. The Sport Psychologist, 20(2), 128-144.

Cumhurbaşkanlığı Teşkilatı Hakkında Cumhurbaşkanlığı Kararnamesi (2018). T.C. Cumhurbaşkanlığı Resmi Gazete, 10/7/2018 tarihli ve 30474 sayıl.. [https://www.mevzuat.gov.tr/MevzuatMetin/19.5.1.pdf], Erişim Tarihi: 29 Nisan 2020. 
Çubukçu, Z., Yılmaz, B.Y. \& İnci, T. (2016). Karşılaşırmalı eğitim programları araştırma eğilimlerinin belirlenmesi-bir içerik analizi. Uluslararası Türkçe Edebiyat Kültür Eğitim Dergisi, 5(1), 446-468.

Donuk, B. (2019). Tam yol yönetim çağdaş spor yönetim ilkeleri. İstanbul: Ötüken Neşriyat A.Ş.

Gençlik ve Spor Hizmetleri Kanunu (1986). T.C. Cumhurbaşkanlığı Resmi Gazete, 28/5/1986 tarihli ve 19120 sayıll. [https://www.mevzuat.gov.tr/MevzuatMetin/1.5.3289.pdf], Erişim Tarihi: 14 Mart 2020.

Johnson, S.R., Wojnar, P.J., Price, W.J., Foley, T.J., Moon, J.R., Esposito, E.N. \& Cromartie, F.J. (2011). A coach's responsibility: Learning how to prepare athletes for peak performance. Sport Journal, 14(1), 13.

Knowles, Z., Gilbourne, D., Borrie, A., \& Nevill, A. (2001). Developing the reflective sports coach: A study exploring the processes of reflective practice within a higher education coaching programme. Reflective practice, 2(2), 185-207.

Nelson, L.J. \& Cushion, C.J. (2006). Reflection in coach education: The case of the national governing body coaching certificate. The Sport Psychologist, 20(2), 174-183.

OECD. (2020). A framework to guide an education response to the COVID-19 pandemic of 2020. Paris: OECD Publishing.

Özbey, Ö., Akoğlu, H. E. \& Polat, E. (2019). Investigation of the activities of the ministry of youth and sports for sustainable success in sports. International Journal of Social Science Research, 8(2), 42-59.

Sevim, Y., Tuncel, F., Erol, E. \& Sunay, H. (2001). Antrenör eğitimi ve ilkeleri. Ankara: Gazi Kitapevi.

Spor Hizmetleri Genel Müdürlüğ̈̈. (2020). İstatistikler. [https://shgm.gsb.gov.tr/Sayfalar/175/105/Istatistikler], Erişim Tarihi: 20 Nisan 2020.

Sunay, H. (2017). Spor Yönetimi. Ankara: Gazi Kitabevi.

Sunay, H. ve İmamoğlu, A. F. (1996). Türkiye'de Antrenör Eğitim Programlarının Etkinliği. Gazi Beden Eğitimi ve Spor Bilimleri Dergisi, 1(3), 66-84.

Telli Yamamoto, G., ve Altun, D. (2020). Coronavirüs ve Çevrimiçi (Online) Eğitimin Önlenemeyen Yükselişi, Üniversite Araştırmaları Dergisi, 3(1), 25-34.

Türkiye Cumhuriyeti Anayasası (1982). T.C. Cumhurbaşkanlığı Resmi Gazete, 9/11/1982 tarihli ve 17863 sayılı. [https://www.mevzuat.gov.tr/MevzuatMetin/1.5.2709.pdf], Erișim Tarihi: 10 Nisan 2020.

UNESCO. (2020). Teacher Task Force calls to support 63 million teachers touched by the COVID-19 crisis. UNESCO. [https://en.unesco.org/news/teacher-task-force-calls-support-63-million-teachers-touchedcovid-19-crisis], Erişim Tarihi: 13 Mayıs 2020.

Ültanır, G. (2000). Karşılaş̧ırmalı eğitim bilimi: Kuram ve teknikler. Ankara: Eylül Kitap ve Yayınevi.

Yücel, A. S. ve Devecioğlu, S. (2012). The usage of information and communication technologies in sport education. Sport Sciences, 7, 1-17.

Ziyagil, M. A. ve Sevimli, D. (2013). Avrupa Birliği ile uyum sürecinde yükseköğretimde antrenörlük eğitiminin yeniden yapılanması. Atatürk Üniversitesi Beden Eğitimi ve Spor Dergisi, 1(15), 9-28.

Ziyagil, M. A. (2020) Antrenörlük mesleki etkililiğinin 30978 sayılı antrenör eğitimi yönetmeliği kapsamında değerlendirilmesi. Spor Eğitim Dergisi, 4(1), 123-136.

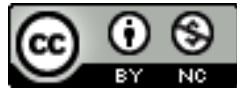

Bu eser Creative Commons Atıf-GayriTicari 4.0 Uluslararası Lisansı ile lisanslanmıştır. 